\title{
Tinjauan Hukum Islam terhadap Adat Hogo Jako dalam Perkawinan di Tidore
}

\author{
Boki Nursafaat Ramadhani, Ramdan Fawzi, Ilham Mujahid \\ Program Studi Hukum Keluarga Islam, Fakultas Syariah, Universitas Islam Bandung \\ Jl. Tamansari No. 140116 \\ Bokinursafaat@gmail.com, RamdanFauzi@unisba.ac,id, ilhammujahid@unisba@ac.id
}

\begin{abstract}
Abstarct-idore adheres to ancient customs and traditions that were carried out by the ancestors of the Tidore tribe. In the celebration procession in marriage there is a sequence that must be carried out by both the bride and groom, and the two bride and groom know. They believe if all the wedding processions both before and after are the norms that must be taken by each bride and groom in a traditional way. Seeing this, the author conducted a study with three main focus discussions to review the traditional marriage law in Tidore with Islamic law with the aim of first, knowing how to carry out marriages in Islamic law, secondly how to carry out marriages in customary law in Tidore, then how to review Islamic law on customary Hogo Jako in marriage at Tidore.
\end{abstract}

\section{Keywords - traditional tidore marriage,Islamic lawI}

Abstrak-Tidore menganut kepada adat dan tradisi zaman dahulu yang telah dilakukan oleh nenek moyang suku Tidore. Dalam prosesi hajatan dalam perkawinan terdapat runtutan yang harus dilakukan oleh kedua mempelai maupun kedua orang tau calon mempelai. Mereka percaya apabila semua prosesi pernikahan baik sebelum maupun sesudah merupakan norma yang harus ditempuh setiap pasangan mempelai secara adat, Melihat hal itu, maka penulis melakukan penelitian dengan tiga fokus pokok pembahasan guna untuk meninjau hukum adat perkawinan yang ada di Tidore dengan hukum Islam dengan tujuan yaitu pertama, mengetahui bagaimana pelaksanaan perkawinan dalam hukum Islam,kedua bagaimana pelaksanaan perkawinan dalam hukum adat di Tidore, kemudian bagaimana tinjauan hukum Islam terhadap adat Hogo Jako dalam perkawinan di Tidore.

Kata kunci-Perkawinan Adat Tidore,Hukum Islam.

\section{PENDAHULUAN}

Pernikahan merupakan salah satu fase dari kehidupan manusia ,bermula dari fase serba sendiri berpindah menjadi fase serba saling pengertian,saling membutuhkan dan saling memenuhi, maka tidak jarang suatu keluarga yang mengadakan akad pernikahan dan prosesi sebagai peristiwa besar terlalu begitu saja Manusia diciptakan Allah sang Maha pencipta secara berpasang-pasangan juga tidak sama baik dalam iman, warna kulit dan yang lebih kongkrit lagi mengenai suku dan bangsa. Indah sekali gambaran keterjadian hamba disebut manusia . Berawal dari Adam kemudian diciptakan pasangannya yaitu Hawa, berlanjut dengan adanya keturunan ,dan semua itu bertujuan hanya untuk bertaqwa kepada Allah .1 Allah menciptakan manusia berbeda jenis ada laki-laki dan perempuan yang bertujuan bisa saling mencintai dan menyayangi serta mewujudkan rumah tangga yang sakinah, mawaddah, dan rahmah . Untuk mencapai tujuan tersebut ,Islam menawarkan aturan-aturan dan prosedur yang harus dipenuhi baik dalam cara peminangan dan prosesi pernikahan .

Apabila kita menengok pada zaman Rasulullah abad yang lalu, bahwa pernikahan adalah suatu acara suka cita , rasa syukur dan luapan kebahagiaan. Sebagai manifestasi rasa syukur tersebut diadakanlah pelaksanaan pernikahan dengan memanggil saudara-saudara, tetangga dan handai tautan dengan maksud hubungan kedua makhluk berbeda jenis sah melalui jenjang pernikahan diketahui oleh banyak orang

\section{LANDASAN TEORI}

Perkawinan yang dalam istilah agama disebut "Nikah" ialah melakukan suatu akad atau perjanjian untuk mengikatkan diri antara seorang laki-laki dan wanita untuk menghalalkan hubungan kelamin antara kedua belah pihak untuk mewujudkan suatu hidup berkeluarga yang diliputi rasa kasih sayang dan ketentraman (mawaddah wa rahmah) dengan cara-cara yang diridhai oleh Allah SWT.2

Perkawinan ialah ikatan lahir bathin antara seorang pria dengan seorang wanita sebagai suami isteri dengan tujuan membentuk keluarga (rumah tangga) yang bahagia dan kekal berdasarkan Ketuhanan Yang Mahaesa.3

Pernikahan adalah suatu pokok yang terpenting untuk hidup dalam pergaulan yang sempurna yang diridhai Allah SWT.4Perkawinan bukan saja terjadi pada manusia tetapi juga terjadi pada tanaman, tumbuhan dan hewan. Pernikahan merupakan kebutuhan alami yang diakui dalam masyarakat, dan Allah telah menciptakan manusia dengan jenis yang berbeda agar mereka saling kenal mengenal.5

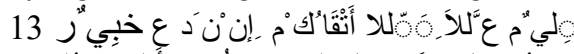

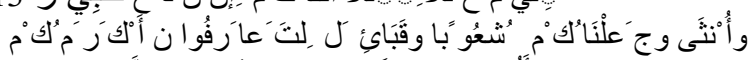

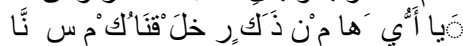

Hai manusia, sesungguhnya Kami menciptakan kamu dari seorang laki-laki dan seorang perempuan dan menjadikan kamu berbangsa-bangsa dan bersuku-suku supaya kamu saling kenal-mengenal.Sesungguhnya orang yang paling mulia diantara kamu disisi Allah ialah, orang yang paling takwa diantara kamu. Sesungguhnya Allah Maha Mengetahui lagi Maha Mengenal.(Al-Hujurat/49:13

Syarat-syarat perkawinan merupakan dasar bagi sahnya perkawinan. Apabila syarat- syarat tersebut dipenuhi, maka sah perkawinan tersebut dan dalam 
perkawinan ini akan menimbulkan kewajiban dan hak bagi suami isteri. Dan mereka akan dapat meraih kehidupan dengan bahagia dalam jalinan kehidupan rumah tangga. ${ }^{6}$ Perkawinan dalam ajaran Islam ada aturan yang perlu dipatuhi oleh calon mempelai serta keluarganya agar perkawinan yang dilakukan sah secara agama sehinga mendapatkan ridha dari Allah SWT.

Untuk melaksanakan perkawinan harus ada :

1. Calon Suami

2. Calon Isteri

3. Wali Nikah

4. Dua orang saksi dan

5. Ijab dan Kabul 7

Salah satu contoh dari sekian banyak pernikahan adat yang ada di Indonesia adalah budaya pernikahan masyarakat Tidore. Berbagai kebiasaan tumbuh dan berkembang di masyarakat Tidore .dalam banyak hal berpadu antara kebiasaan luhur dan tradisi Islam. Keduaduanya hidup berdampingan secara damai , selama keduaduanya saling membutuhkan dan tidak terjadi benturan .Disunnahkan mengadakan upacara pernikahan yang terdapat di dalam hadist Rasullah SAW.

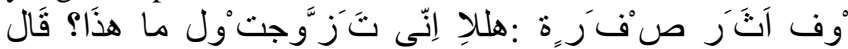

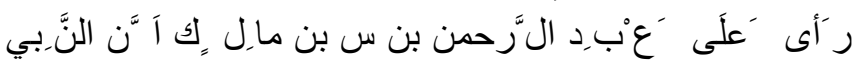

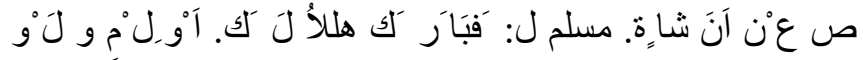

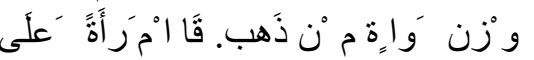

Dari Anas bin Malik, bahwasanya Nabi SAW melihat ada bekas kuning-kuning pada 'Abdur Rahman bin 'Auf. Maka beliau bertanya, "Apa ini ?". Ia menjawab, "Ya Rasulullah, saya baru saja menikahi wanita dengan mahar seberat biji dari emas". Maka beliau bersabda, "Semoga Allah memberkahimu.Selenggarakan walimah meskipun (hanya) dengan (menyembelih) seekor kambing". [HR. Muslim].

Setiap masyarakat mempunyai sistem sosial yang berbeda antara satu dan yang lain, maka hukum Islam pun berkembang dengan bentuk-bentuk yang berbeda pula, perkembangan hukum Islam yang berbeda itu salah satunya ditandai dengan adanya 'urf .Kajian tentang perkawinan adat hogo jako di Tidoreini sangat erat kaitannya dengan 'urf . Pengertian 'urf adalah sikap, dan perkataan yang "biasa" dilakukan oleh kebanyakan manusia atau manusia secara keseluruhan.Urf ditinjau dari ruang lingkup berlakunya, yaitu mengenai adatdan kebiasaan kita, 'urf ini dibagi menjadi dua macam yaitu:

1. Adat atau 'urf yang bersifat umum, yaitu adat kebiasaan yang berlaku untuk semua orang di semua negeri. Misalnya membayar bis kota dengan tidak menggunakan akad ijab qobul dan juga contoh pesanan diatas.

2. Adat atau 'urf yang khusus, yaitu hanya berlaku di suatu daerah tertentu saja. Misalnya adat gono-gini dalam adat di Jawa.8
Para ulama' ushul fiqih membedakan antara adat dengan uruf dalam membahas kedudukannya sebagai salah satu dalil untuk menetapkan hukum syara'. Adat didefinisikan

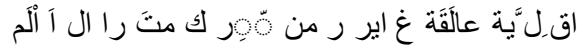

"Sesuatu yang dikerjakan secara berulang-ulang tanpa adanya hubungan rasional"

Sementara kajian adat Hogo jako pernikahan adat di Tidore juga sangat erat kaitannya dengan'urf fi'li,dalam istilah lain disebut juga 'urf 'amali adalah sejenis pekerjaan atau aktifitas tertentu yang sudah biasa dilakukan secara terus menerus, sehingga dipandang sebagai norma sosial, contohnya adalah penggunaan pakaian adat, atau pakaian sehari-hari dari etnis dan golongan tertentu atau persamaan dalam saat resepsi pernikahan.

Syarat-syarat 'urf yang dapat dijadikan sumber penetapan hukum, yaitu:

1. Tidak bertentangan dengan nash yang qat' $i$

2. urf harus berlaku universal. Tidak dibenarkan 'urf yang menyamai 'urf lainnya karena adanya pertentangan antara mereka yang mengamalkan dan yang meninggalkan.

3. 'urf harus berlaku selamanya. Tidak dibenarkan 'urf yang datang kemudian.9

\section{HASIL PENELITIAN DAN PEMBAHASAN}

Sebagai suatu bentuk tujuan untuk meningkatkan keimanan dan ketakwaan masyarakat Tidore terhadap Tuhan Yang Maha Esa, pemahaman mengenai agama juga sangat penting bagi penduduk kota Tidore. Dengan masing-masing kepercayaan dan keyakinannya, untuk meningkatkan kualitas kehidupan beragama dan tetap terpeliharanya kerukunan antar umat beragama, serta meningkatkan kesadaran dalam melaksanakan pembangunan.Berdasarakan keterangan yang didapatkan, menunjukkan bahwa penduduk Kota Tidore Kepulauan mayoritas beragama Islam, hal tersebut di tandai dengan tempat peribatan bagi penganut agama Islam terlihat lebih menonjol dari agama yang lainnya. Selain agama Islam ada juga penganut agama lain. Hal ini, dapat dilihat dengan jumlah jiwa dan persentasinya yaitu penduduk yang beragama Islam (86.696 jiwa atau 94,07\%), Kristen (4.120 jiwa atau 4,47\%), Katolik (89 jiwa atau 0,097\%), Hindu (7 jiwa atau 0,008\%), Budha

(5 jiwa atau 0,005\%), dan Kong Hucu (1 jiwa atau $0,001 \%) .10$

Penduduk kota Tidore dengan mayoritas agamanya adalah Islam, dapat dilihat pada tempat peribadatan (Mesjid dan Mushollah) yang sangat banyak. Dalam satu desa/kelurahan, terdapat Mesjidnya masing-masing. Desa yang memiliki luas wilayah yang terdiri dari beberapa RT/RW terdapat lebih dari satu mesjid dan juga Musholla. Setiap Jum'at, masyarakat Tidore berbondong-bondong menunaikan Shalat Jum'at, baik laki-laki maupun perempuan. Begitu juga pada waktu bulan Ramadhan 
biasanya, penduduk dari desa lain yang jaraknya tidak terlalu jauh dari desa yang satu, datang ke mesjid desa yang lebih besar utuk sama-sama melakukan shalat Tarawih. Selain agama Islam yang di anut oleh masyarakat Tidore, terdapat juga agama lain yang merupakan penduduk pendatang, yang berdomisili di Tidore. Dengan masing-masing tempat peribadatannya. Tetapi tempat peribadatannya hanya terdapat di kecamatan Tidore yang merupakan pusat Kota Tidore.

Dengan mayoritas penduduknya adalah Islam, mereka sangat menjunjung tinggi nilai- nilai keagamaan, hal ini juga dapat dilihat setiap sore atau setelah shalat magrib. Anak-anak mereka yang masih duduk dibangku SD sampai dengan SMP diwajibkan belajar mengaji baik di taman pengajian yang telah dibangun di tiap-tiap desa atau di mesjid-mesjid terdekat di desa mereka yang dimulai pada sore hari setelah shalat ashar atau sesudah shalat magrib hingga shalat isya. Kadang orang tua mereka mengefaluasi mengajinya di rumahnya masing- masing. Bagi muridmurid yang telah tamat Al-Qur'an (Iqra') akan diikutkan wisuda tamatan Al-quran yang biasanya dilaksankan berpusat di Kecamatan Tidore. Sementara bagi murid yang sudah tamat membaca Al-Quran 30 juz maka dilaksanakan acara selamatan di rumahnya, biasanya dirangkaian dengan acara sunatan jika salah satu keluarganya melaksanakan acara sunatan tersebut.Selain itu selamatan juga dilaksanakan untuk orang yang hendak menunaikan ibadah haji. Mereka berkumpul dan bersama-sama membantu

untuk melaksanakan acara ini sebab status haji bagi masyarakat Tidore merupakan suatu hal yang penting dan di anggap terhormat karena telah mampu menunaikan rukun Islam ynag kelima. Sehingga mereka dipandang sebagai seorang imam bagi kehidupan bermasyarakat.

Masyarakat Tidore Kepulauan memiliki kehidupan sosial yang beragam yaitu dengan berbagai macam etnis yang datang dan menetap di daerah ini. Terdapat dua golongan dalam masyarakat ini yaitu pertama, golongan tradisional yakni golongan yang masih tetap kuat memegang dan menyelenggarakan tradisi-tradisi leluhur yang sudah menjadi ciri khas masyarakat Tidore. Kedua, golongan modern yaitu masyarakat yang sudah mengalami pengaruh modernisasi dalam gaya hidupnya. Masingmasing kecamatan memiliki tradisi serta adat istiadatnya, baik itu dalam bidang kesenian, ataupun tata cara pekawinan. Kesenian yang dimaksud adalah berbagai macam seni tari dengan tujuannya masing-masing dan ada juga ritual mengunjungi makam leluhur dengan membawa sesajen yang biasanya hanya dilakukan oleh masyarakat Tidore kecamatan Tidore Utara.

Meskipun masing-masing kecamatan memiliki adat tersendirinya namun tetap bersendi pada adat istiadat asli Tidore. Seperti yang telah dijelaskan di atas bahwa pelaksanaan Hogo Jako tidak dilaksanakan di seluruh kecamatan yang ada di Tidore, tetapi jika ada yang menikah dengan kecamatan yang masih kental memegang adat istiadat tersebut, mereka tetap melaksanakan ritual ini sesuai dengan kesepakatan kedua belah pihak yang melangsungkan pernikahan. Kecamatan-keamatan tersebut adalah kecamatan Tidore dan Kecamatan Tidore Utara. Dua kecamatan ini berdasarkan silsilah memang paling banyak terdapat keturunan bangsawan atau para 'Bobato' (semacam pemangku adat) untuk Kesultanan Tidore, dan juga kedua kecamatan ini juga paling banyak peninggalan sejarahnya atau tempat-tempat yang dikeramatkan. sehinga kebiasaan-kebiasaan leluhur yang telah diwariskan tetap mereka pertahankan dan dilestarikan.11

Bersamaan dengan kegiatan malam rorio, di kediaman mempelai wanita sebelumnya telah dilaksanakan salah satu ritual yaitu hogo jako (mandi bersih diri dan tolak bala). Utusan calon pengantin wanita dengan menggunakan baju adat menjemput calon pengantin pria. Calon pengantin wanita duduk diatas pangkuan seorang wanita muda dan calon pengantin pria di pangku seorang lelaki muda. Mereka dililitkan dengan kain putih dan kepalanya juga ditutupi kain putih.

Di depan pengantin berdiri para ibu yaya goa selaku pelaksana prosesi lengkap dengan busana adat (dao). Perlengkapan hogo jako terdiri dari : bambu berisi air yang dililitkan dengan kain putih, telur, buah pisang, pinang, mayang pinang yang di atasnya telah diikat sumbu (jumlahnya ganjil), sirih, kapur, pelita, uang koin, dan daun beringin muda. Makna prosesi ini adalah upaya untuk menolak segala marabahaya menjelang pernikahan maupun sesudahnya.12

Sudah menjadi suatu keharusan di masyarakat Tidore melewati prosesi Hogo Jako sebelum akad berlangsung dan biasanya terjadi di pagi hari , dengan begitu banyak

masyarakat berkumpul dan para pemuka adat khususnya perempuan menyiapkan segala bahan untuk Hogo Jako .ketika sang mempelai wanita keluar dia wajib ditutupi wajahnya dan menuju tempat duduk yang sedang disiapkan . para mempelai harus dipangku saat dimandikan dan biasanya oleh saudara terdekat yang belum menikah, konon bisa memperlancar jodoh bagi yang memangku .kedua mempelai ditutupi oleh kain putih kemudian seperti dupa dinyalakan dengan api bersamaan dengan air juga arang yang dibakar dengan api kecil dimandikan pada kedua mempelai secara bersamaan,tentunya yang memandikan harus tetua adat perempuan dengan membaca doa khusus .13

Menurut qadhi kesultanan Tidore semua prosesi dalam perkawinan baik sebelum dan sesudah perkawinan sudah menjadi tradisi yang turun temurun yang sudah seharusnya dilaksanakan dan sudah menjadi norma wajib dalam masyarakat Tidore . begitu juga dengan Hogo Jako yang sudah menjadi norma dalam masyarakat Tidore yang mayoritas muslim. 


\section{KESIMPULAN}

Berdasarkan hasil penelitian yang telah dilakukan dapat disimpulkan :

1. Dalam surat Ar-rum ayat 21 juga menjelaskan bahwa pernikahan merupakan tanda-tanda kekuasaan Tuhan untuk mewujudkan hubungan kekerabatan yang rukun dan damai . Dalam islam telah mengatur syarat dan rukun menikah, begitu juga dengan walimah dalam perkawinan .berdasarkan dengan hadist bahwa harus melakukan walimah meskipun hanya menyembelih seekor kambing . mayoritas ahli fiqh berpendapat walimah itu sunnah muakkad tapi tetap ada ulama yang berpendapat bahwa walimah itu tidak wajib . tapi tentunya ada beberapa yang harus diperhatikan dalam menyelenggarakan walimah. Maka tata pelaksanaan perkawinan dalam Hukum Islam tentunya sesuai dengan syarat dan rukun yang sudah jelas kemudian walimah yang dianjurkan diselenggarakan walaupun hanya menyembelih seekor kambing .

2. Di Tidore pernikahan merupakan suatu hal yang sangat disakralkan dan begitu banyak ritual yang harus dilakukan baik sebelum dan sesudah menikah dan kebiasaan yang berlangsung di masyarakat Tidore kemudian menjadi norma yang wajib dilaksanakan dalam setiap perkawinan.seperti penulis yang membahas runutan prosesi pernikahan baik sebelum dan sesudah terutama tentang Hogo Jako yang sudah menjadi keharusan untuk dilaksanakan dalam setiap pernikahan .prosesi pernikahan mulai dari masusu lahi ,paka den, pengajian bersamaan dengan membaca perjanjian, malam rorio , Hogo jako sampai dengan makan saro.

3. Berkaitan dengan adat istiadat, dalam prosesi perkawinan adat desa Tidore ini juga dapat pandang dari segi ushul fiqih yaitu ,urf fi ${ }^{\text {ee }}$ li(kebiasaan perbuatan), yang mana berbentuk perbuatan. Namun syarat urf untuk menjadi sumber penetapan hukum ada beberapa antara lain itu tentunya tidak bertentangan dengan nash yang qat'i , urf berlaku universal, urf berlaku selamanya . Jadi menurut analisa penulis mengenai perkawinan adat di Tidore adalah termasuk adat kebiasaan yang berlaku di masyarakat dan sudah berlaku sejak lama, jika.tidak memiliki pertentangan dengan nash AlQurean dan hadits, maka adat istiadat itu boleh di berlakukan, berhukum mubah (boleh). Tetapi apabila melaksanakan upacara perkawinan adat disertai sesaji yang sengaja dibuat dengan niat meminta keselamatan kepada selain Allah itu yang dilarang dalam syariat agama Islam.

\section{DAFTAR PUSTAKA}

Buku :

[1] Siregar Bismar, Bunga rampai dan Hukum Islam ,(Grafikatama Jaya 1992) Hadiyah Salim, Memilih Jodoh ,(Bandung : PT.Alma'arif 1980)

[2] Rahman Ghazali,Fiqh Munakahat , (Jakarta : Prenada Media ,2003)

[3] Djazuli, Ilmu Fiqh Sebuah Pengantar,(Bandung: Percetakan Orba Shakti, 1992) Rachmat Syafe' i, Ilmu Ushul Fiqh, (Bandung: Pustaka Setia, 2007)

[4] Irham Rosyidi,S.H.,M.H. Ketatanegaraan Kesultanan Tidore (Malang 2009)

[5]

[6] Soemiyati, Hukum Perkawinan Islam dan Undang-undang Perkawinan, Yogyakarta, (Liberty Yogyakarta 1989), hlm.9. 